\title{
The Cultural Assessment Model as an Evaluation Indicator for Nutritional Adequacy in Pregnant Women with Pre-eclampsia
}

\author{
Awatiful Azza ${ }^{1 *}$ iD, Cipto Susilo² \\ ${ }^{1}$ Department of Maternity and Child Nursing, Universitas Muhammadiyah Jember, Jember, Indonesia; ${ }^{2}$ Cardiovascular \\ Department, Universitas Muhammadiyah Jember, Jember, Indonesia
}

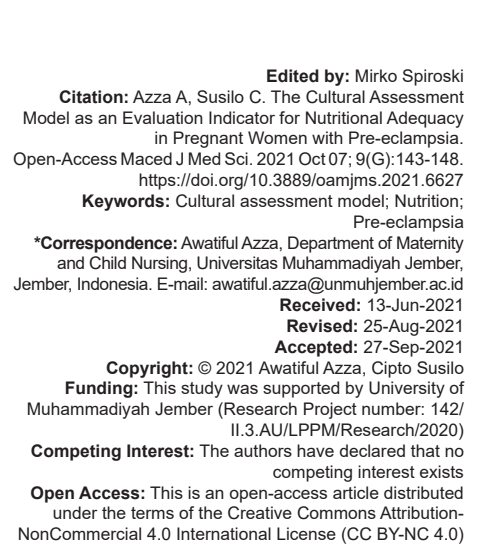

Introduction

Pregnancy is a physiological condition in the development of a woman's life [1], [2], [3]. Pre-eclampsia is one of the complications in pregnancy that case is likely to increase and at risk of being a major cause of mortality and morbidity in pregnant women and fetuses both in developed and developing countries [4], [5], [6]. Data on the incidence of pre-eclampsia in the developed countries range from $6 \%$ to $7 \%$ of all pregnancies, while the prevalence in developing countries goes to $16.7 \%$ and is estimated to cause approximately $40-60 \%$ of maternal deaths [6], [7], [8]. In Indonesia, the incidence of pre-eclampsia is 128.273 cases $(20.22 \%)$ in 2019 and causes $24 \%$ of maternal mortality [9].

Another impact of pre-eclampsia is growthrelated disorders, the development of intrauterine growth retardation [8], [10], [11], and intrauterine fetal death [12], [13]. Pre-eclampsia may occur during the antenatal, intrapartum, and postnatal with symptoms of hypertension, protein in the urine (proteinuria), and edema [6], [14], [15]. Although the cause of pre-eclampsia is still unclear, there seem to be some specific factors such as age, nulliparity, body mass index, mother's diet, hypertension, preexisting, history of pre-eclampsia, kidney disease, and diabetes mellitus [4], [16], [17], [18], [19].
Culture has an important role in the nutritional status of pregnant women because of several beliefs [20],[21], [22]. Habits of excessive food consumption for pregnant women, beliefs about dietary restrictions for pregnant women, and values related to health and religion that have been trusted since childhood can be a risk factor for preeclampsia [23], [24], [25].

An assessment model in pregnant women using the cultural model is one of the ways to find out the problems related to nutrition consumed by pregnant women [26], [27]. The transcultural approach is the cultural background oriented, such as values, beliefs, rules of behavior, and lifestyle practices that become the benchmark for thinking and acting [26], [28]. The mother needs social support during pregnancy to trigger her confidence to be wellprepared before having childbirth [29]. This study aims to find out the nutritional adequacy for pregnant women through the transcultural model assessment.

\section{Materials and Methods}

This study used a correlational design with a crosssectional approach in pregnant women at trimester intended 
to analyze the Transcultural Model Assessment (Figure 1) as an Indicator of Analysis the Evaluation of Nutritional Adequacy in Pregnant Women with Pre-eclampsia.

Data collection was performed in the unit of outpatient hospital referral for pre-eclampsia cases from June 2019 to June 2020. All pregnant women who came to the unit were the population in this study, the sampling technique was purposive sampling with the inclusion criteria of gestational age more than 28 weeks, with a sample of 222 pregnant women. Assessment of the diagnosis of preeclampsia was identified by measuring blood pressure of $140 / 90 \mathrm{mmHg}$ or higher at least two measurements $4 \mathrm{~h}$ apart at gestational age over 20 weeks of gestation and laboratory diagnosis taken from urine showing protein excretion.

The data include primary data and secondary data. The first is obtained directly from pregnant women as a source of data through a questionnaire about eating habits in the past 3 months using the transcultural assessment is an assessment of family daily eating habits based on cultural values and dietary restrictions in families for pregnant women and interviews. The latter was obtained through document study of medical records or visiting cards.

The data analysis was performed using the Chisquare test, odds ratio (OR) with $95 \%$ confidence intervals $(\mathrm{Cl})$, and the alpha value of 0.05 . To complement this study, the researchers presented quantitative data in the table of frequency on the results of culture and habits mapping of food consumption in pregnant women during pregnancy.

\section{Ethical considerations}

This study was approved by the Ethics Committee of the Faculty of Health Sciences, Muhammadiyah University of Jember (Number 307/ KEPK/FIKES/IX/2020). Respondents were previously informed of the aims and procedures of the study. Furthermore, participation is voluntary with written informed consent obtained.

\section{Results}

\section{Characteristics of pregnant women}

The characteristics of pregnant women are presented in Table 1.

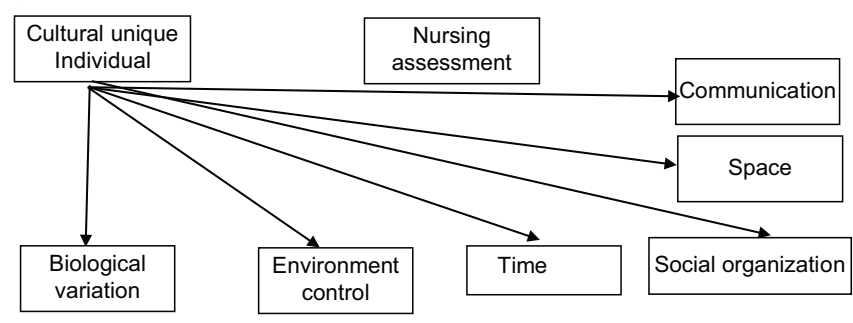

Figure 1. Giger and Dhavidizhar's Transcultural assessment model [30]
Table 1: The characteristics of pregnant women by age, educational background, occupation, household income, religion, ethnicity, and family structure $(n=222)$

\begin{tabular}{|c|c|c|}
\hline Variable & Frequency & $\%$ \\
\hline \multicolumn{3}{|l|}{ Age } \\
\hline$<20$ & 24 & 10.8 \\
\hline $20-30$ & 98 & 44.1 \\
\hline$>30$ & 100 & 45 \\
\hline \multicolumn{3}{|l|}{ Educational background } \\
\hline Primary school & 95 & 42.6 \\
\hline Junior high school & 60 & 26.9 \\
\hline Senior high school & 55 & 24.7 \\
\hline Higher education & 12 & 5.4 \\
\hline \multicolumn{3}{|l|}{ Occupation } \\
\hline Housewife & 192 & 86.1 \\
\hline Laborer & 21 & 9.5 \\
\hline Entrepreneur/self-employer & 7 & 3.2 \\
\hline Civil servant & 2 & 9 \\
\hline \multicolumn{3}{|l|}{ Household income } \\
\hline$<2$ million rupiah & 195 & 87.4 \\
\hline 2-3 million rupiah & 24 & 10.8 \\
\hline$>3$ million rupiah & 3 & 1.4 \\
\hline \multicolumn{3}{|l|}{ Religion } \\
\hline Islam & 220 & 99.1 \\
\hline Christian & 2 & 9 \\
\hline \multicolumn{3}{|l|}{ Ethnicity } \\
\hline Javanese & 40 & 18 \\
\hline Madurese & 180 & 81.1 \\
\hline Other & 2 & 0.9 \\
\hline \multicolumn{3}{|l|}{ Family structure } \\
\hline Core family & 82 & 36.8 \\
\hline Extended family & 132 & 59.5 \\
\hline $\begin{array}{l}\text { Joint family (living under one roof with own } \\
\text { parents/parents-in-law) }\end{array}$ & 8 & 3.6 \\
\hline Sub-total & 222 & 100 \\
\hline
\end{tabular}

\section{Characteristics of nutritional adequacy by} the cultural assessment

The characteristics of nutritional adequacy in pregnant women by daily nutrition are presented in Table 2.

\section{Analysis of nutritional adequacy and} incidence of pre-eclampsia

Analysis of nutritional adequacy and incidence of pre-eclampsia is presented in Table 3.

Based on the analysis of nutritional adequacy with the incidence of pre-eclampsia, the types of food (i.e., carbohydrates with $p=0.00$ and the OR 5.250, protein with $p=0.004(\mathrm{OR}=3.545$, $95 \% \mathrm{Cl}=2.098,13.158)$, folic acid with $\mathrm{p}=0.00$ $(\mathrm{OR}=16.838,95 \% \mathrm{Cl}=2.222,127.64)$, and vegetable with $p=0.001$ (OR of $4.00,95 \% \mathrm{Cl}=1.619,9.885$ ) are closely related to the incidence of pre-eclampsia in pregnant women. For those whose daily diet is excess of carbohydrates, there was a chance of pre-eclampsia 5.25 times compared to those whose daily menu is less carbohydrates. Those whose daily menu less was less in folic acid would be at risk of 17.667 times undergoing pre-eclampsia.

The result of beliefs and cultural practices during pregnancy such as the assessment of culture in support of the nutritional adequacy in pregnant women is presented in Table 4 while the assessment of prohibitions/abstinence on daily nutrition during pregnancy is listed in Table 5. 
Table 2: Tabulation of frequency on characteristics of nutritional adequacy in pregnant women by daily nutrition $(n=222)$

\begin{tabular}{lllll}
\hline Variable of nutrition & Frequency & & Mean & Standard deviation \\
\cline { 2 - 3 } & Deficient & Sufficient & & \\
\hline Carbohydrates (rice, potatoes, sweet potatoes, corn) & 43 & 179 & 1.8063 & 0.396 \\
Protein (tofu, tempeh, eggs, fish, meat) & 55 & 167 & 0.7523 & 0.432 \\
Folic acid (sea fish, vitamins) & 132 & 90 & 1.4054 & 0.492 \\
Fruit (all types of fruit) & 10 & 212 & 1.9550 & 0.621 \\
Milk (fresh milk, yogurt, formula milk) & 102 & 120 & 1.5405 & 0.1 .866 \\
Vegetables (all types of vegetables) & 51 & 171 & 1.7703 & 0.499 \\
Calcium (calc) & 119 & 103 & 1.4640 & 0.421 \\
\hline
\end{tabular}

Table 3: Analysis of nutritional adequacy and incidence of pre-eclampsia $(n=222)$

\begin{tabular}{|c|c|c|c|c|c|c|}
\hline \multirow[t]{2}{*}{ Variable } & \multirow[t]{2}{*}{ Not pre-eclampsia } & \multirow[t]{2}{*}{ Pre-eclampsia } & \multirow[t]{2}{*}{$\mathrm{p}$-value } & \multirow[t]{2}{*}{ OR } & \multicolumn{2}{|l|}{$\mathrm{Cl} 95 \%$} \\
\hline & & & & & Lower & Upper \\
\hline \multicolumn{7}{|l|}{ Carbohydrate } \\
\hline Deficient & 11 & 32 & 0.00 & 5.250 & 2.098 & 13.158 \\
\hline Sufficient & 11 & 168 & & & & \\
\hline \multicolumn{7}{|l|}{ Protein } \\
\hline Deficient & 11 & 44 & 0.004 & 3.545 & 1.441 & 8.722 \\
\hline Sufficient & 11 & 156 & & & & \\
\hline \multicolumn{7}{|l|}{ Folic acid } \\
\hline Deficient & 21 & 111 & 0.00 & 16.838 & 2.222 & 127.64 \\
\hline Sufficient & 1 & 89 & & & & \\
\hline \multicolumn{7}{|l|}{ Fruits } \\
\hline Deficient & 10 & 0 & 0.00 & 17.667 & 10.197 & 30.607 \\
\hline Sufficient & 12 & 200 & & & & \\
\hline \multicolumn{7}{|l|}{ Milk } \\
\hline Deficient & 11 & 91 & 0.688 & 1.198 & 0.496 & 2.890 \\
\hline Sufficient & 11 & 109 & & & & \\
\hline \multicolumn{7}{|c|}{ Vegetables (all types of vegetables) } \\
\hline Deficient & 11 & 40 & 0.001 & 4.00 & 1.619 & 9.885 \\
\hline Sufficient & 11 & 160 & & & & \\
\hline \multicolumn{7}{|c|}{ Calcium (calc) } \\
\hline Deficient & 11 & 108 & 0.721 & 0.852 & 0.353 & 2.055 \\
\hline Sufficient & 11 & 92 & & & & \\
\hline
\end{tabular}

\section{Discussion}

Pregnancy is a period that requires more attention, especially in the fulfillment of the nutritional needs of the mother and the fetus [31], [32]. Therefore, pregnant women require nutritious food to make themselves and their baby safe, especially during the conception period that consists of protein, vitamins, calcium, folic acid, and energy [15].

Table 4: Assessment of culture in support of the nutritional adequacy in pregnant women

\begin{tabular}{|c|c|c|c|}
\hline Activities & Often & Rarely & Never \\
\hline I got my pregnancy checked in a dukun & 18 & 150 & 54 \\
\hline $\begin{array}{l}\text { Parents/mother-in-law taught me about nutrition fulfillment } \\
\text { during pregnancy }\end{array}$ & 198 & 24 & 0 \\
\hline $\begin{array}{l}\text { Community leaders taught me good culture for pregnant } \\
\text { women }\end{array}$ & 178 & 40 & 4 \\
\hline I ate to satiate during my pregnancy & 169 & 37 & 16 \\
\hline $\begin{array}{l}\text { I violated the culture of food consumption habits during my } \\
\text { pregnancy }\end{array}$ & 112 & 12 & 100 \\
\hline $\begin{array}{l}\text { I violated the culture of food consumption habits during my } \\
\text { pregnancy }\end{array}$ & 180 & 40 & 2 \\
\hline $\begin{array}{l}\text { The culture I profess prohibits pregnant women from } \\
\text { consuming sea fish and shrimp }\end{array}$ & 127 & 75 & 20 \\
\hline $\begin{array}{l}\text { My family has important roles in deciding on food consumption } \\
\text { during pregnancy }\end{array}$ & 113 & 78 & 31 \\
\hline Pregnant women must obey the culture in society & 180 & 22 & 20 \\
\hline $\begin{array}{l}\text { Pregnant women should not consume supplements for blood } \\
\text { since it can cause high blood pressure }\end{array}$ & 89 & 68 & 65 \\
\hline I consume an alcoholic drink & 0 & 0 & 222 \\
\hline I have to hold the $7^{\text {th }}$ month pregnancy salvation & 157 & 60 & 8 \\
\hline The food I consume must be cooked first & 193 & 27 & 2 \\
\hline My religion forbids to consume non-halal food & 222 & 0 & 0 \\
\hline $\begin{array}{l}\text { The types of food for eating habits in my family consist of rice, } \\
\text { vegetables, and side dishes }\end{array}$ & 222 & 0 & 0 \\
\hline $\begin{array}{l}\text { I consume foods that contain calcium in my daily menu (e.g. } \\
\text { yogurt, milk, cheese) }\end{array}$ & 15 & 89 & 118 \\
\hline $\begin{array}{l}\text { I consume foods that contain folic acid in my daily menu (e.g. } \\
\text { vegetables, broccoli, tomatoes, cereals, avocados) }\end{array}$ & 45 & 98 & 78 \\
\hline $\begin{array}{l}\text { I avoid consuming food prohibited by my culture during } \\
\text { pregnancy }\end{array}$ & 197 & 14 & 11 \\
\hline
\end{tabular}

During the period of pregnancy, pregnant women need an extra intake of calories of 300-400 kcal per day [32], [33]. They should consume balanced daily nutrition to prevent them from the excess energy that leads to the risk of obesity during pregnancy [14], [15], [34]. The results of this study indicated that the consumption of daily nutrition containing carbohydrates is associated with the incidence of pre-eclampsia with the $\mathrm{p}=0.00(\mathrm{OR}=3.545,95 \% \mathrm{Cl}=$ $2.098,13.158)$. Consuming nutritious food during pregnancy is needed to get energy and support the growth and development of the fetus in the womb. However, a diet with excess carbohydrates will be at risk for pregnant women.

The need for folic acid in pregnant women, especially a few weeks before and after the beginning of pregnancy, is important for the growth of the fetus, the embryo requires folic acid for the formation of the nervous system and cells [35], [36]. An additional $400 \mu \mathrm{g}$ of folic acid per day is necessary during the first trimester of pregnancy [24]. The results of this study showed that $\mathrm{p}=0.00(\mathrm{OR}=16.838,95 \% \mathrm{Cl}=2.222,127.64)$ has a close correlation with the consumption of folic acid and the incidence of pre-eclampsia. Those who had a daily Table 5: Prohibitions/abstinence on food to be obeyed by pregnant women during the pregnancy

\begin{tabular}{ll}
\hline Prohibitions/abstinence to consume & Effects believed by pregnant women \\
\hline Ice & Faster growth (big) when toddler years and \\
& gradually become small \\
Meatball & The baby has a big body \\
Archidendron pauciflorum & The baby smells bad \\
Pineapple & Miscarriage \\
Salted fish & Itching on the mother \\
Thunnini and Sardina pilchardus & Bleeding \\
Banana & Womb displacement \\
Noodles & Womb displacement \\
Jackfruit & Womb displacement \\
Fruits with coincide structure & Conjoined (Siamese) twins \\
\hline Source: Primary data. &
\end{tabular}


menu with less folic acid have a risk of 16,838 times of pre-eclampsia.

According to a research team led by a researcher at Ottawa University, the intake of balance folic acid plays an important role in the development of the placenta [23]. Folic acid has benefits for the formation of endothelial cells, special cells lining the blood vessels throughout the body, and placenta. Other nutrients needed by pregnant women during pregnancy are $60 \mathrm{~g}$ of protein per day (more than $10 \mathrm{~g}$ than usual intake) [8], [15]. Protein can be obtained from meat, fish, egg white, legumes, tofu, tempeh, etc. [16]. The consumption of $1000 \mathrm{mg}$ calcium per day is required to maintain the growth of bones and teeth, muscle contraction, and nervous system [37]. Vitamin A is beneficial for the maintenance of skin, eye function, and bone growth. Iron $(\mathrm{Fe})$ is necessary for blood formation [38]. Vitamin $C$ is beneficial to facilitate the absorption of Fe by the body, in addition to maintaining the health of teeth and gums [15], [39].

Pregnancy leads to an increase in energy metabolism since it needs energy and other nutrients during pregnancy [40]. The increase in energy and nutrients is required for fetal growth and development, the magnitude of organ content, changes in the composition, and metabolism of the mother's body. Accordingly, the lack of certain nutrients in pregnant women may cause risks and complications in their bodies. Many factors may affect the pattern of consumption for daily nutrition in pregnant women, one of them is cultural practices developed and believed in society [33].

In some regions of Indonesia, cultural practices related to pregnancy are preserved. Many rules and myths about abstinence developed in society and it highly affects pregnant women and their families in preparing for the daily menu [32]. The cultural assessment model is appropriate to be used to find out both the positive and negative effects, thus, it can identify the nutritional problems in the community. The concept of cultural assessment adopts the theory of Giger and Davidhizar transcultural assessment model [41], [42], [43].

Leininger (Tomey and Alligood, 2006) said that culture has vast effects on the lives of a family. This may have effects on the health behaviors of the family that includes the habits of daily living, work, social interactions, and health practices. Beliefs, values, culture, and norms that exist within the family may also affect the health of the family [44].

\section{Conclusion}

The fulfillment of daily nutrition in pregnant women is greatly affected by culture and myths developed and believed in society. The assessment using the transcultural model can give a lot of information about the effects of culture in the daily life of pregnant women.

\section{References}

1. Warriner S. Pregnancy and body mass index (BMI). Oxford Univ Hosp. 2016;50:1-10.

2. Magee LA, Pels A, Helewa M, Rey E, von Dadelszen $P$ Canadian Hypertensive Disorders of Pregnancy (HDP) Working Group. Diagnosis, evaluation, and management of the hypertensive disorders of pregnancy. Pregnancy Hypertens. 2014;4(2):105-45. https://doi.org/10.1016/j.preghy.2014.01.003 PMid:26104418

3. Prasetyo B, Winardi B, Pranadyan R, Erlin H, Damayanti MA, Yusuf $M$, et al. Increasing of early high-risk pregnancy detection with proactive intervention in Bangkalan district, Madura Indonesia. J Glob Pharm Technol. 2020;12(6):26-31.

4. Rawlins B, Plotkin M, Rakotovao JP, Getachew A, vaz M, Ricca J, et al. Screening and management of pre-eclampsia and eclampsia in antenatal and labor and delivery services: Findings from cross-sectional observation studies in six sub-Saharan African countries. BMC Pregnancy Childbirth. 2018;18(1):346. https://doi.org/10.1186/s12884-018-1972-1

PMid:30139342

5. Karampas GA, Eleftheriades MI, Panoulis KC, Rizou MD, Haliassos AD, Metallinou DK, et al. Prediction of pre-eclampsia combining NGAL and other biochemical markers with Doppler in the first and/or second trimester of pregnancy. A pilot study. Eur J Obstet Gynecol Reprod Biol. 2016;205:153-7. https://doi. org/10.1016/j.ejogrb.2016.08.034 PMid:27599094

6. Al-Rubaie ZT, Hudson HM, Jenkins G, Mahmoud I, Ray JG Askie LM, et al. Prediction of pre-eclampsia in nulliparous women using routinely collected maternal characteristics: A model development and validation study. BMC Pregnancy Childbirth. 2020;20(1):23. https://doi.org/10.1186/s12884-019-2712-x PMid:31906891

7. Amin O, Tasnim N, Naeem S. Prevention of preeclampsia with low dose aspirin in primigravida. Women's Health. 2020;9(1):28-32. https://doi.org/10.15406/ mojwh.2020.09.00264

8. Burton GJ, Redman CW, Roberts JM, Moffett A. Pre-eclampsia Pathophysiology and clinical implications. BMJ. 2019;366:1-15. https://doi.org/10.1136/bmj.12381

9. Statistics H. Profil Kesehatan Indonesia 2020, Pusat Data dan Informasi Profi Kesehatan Indonesia. Jakarta: Kementerian Kesehatan; 2020. https://doi.org/10.6066/jtip.2013.24.2.121

10. de Souza Rugolo LM, Bentlin MR, Trindade CE. Preeclampsia: Effect on the fetus and newborn. Neoreviews. 2011;12(4):e198-206. https://doi.org/10.1542/neo.12-4-e198

11. Park HJ, Shim SS, Cha DH. Combined screening for early detection of pre-eclampsia. Int J Mol Sci. 2015;16(8):17952-74. https://doi.org/10.3390/ijms160817952 PMid:26247944

12. El Sayed SL, Desoky MM. Effect of lifestyle alteration of pregnant women with mild preeclampsia on maternal and fetal status. JOJ Nurse Health Care. 2019;10(1):1-7.

13. Nooh AM, Abdeldayem HM. Changes in platelet indices during pregnancy as potential markers for prediction of preeclampsia development Open J Obstet Gynecol. 2015;5(12):703-12. 
https://doi.org/10.4236/ojog.2015.512099

14. Aparicio E, Jardí C, Bedmar C, Pallejà M, Basora J, Arija V, et al. Nutrient intake during pregnancy and post-partum: ECLIPSES study. Nutrients. 2020;12(5):1325. https://doi.org/10.3390/ nu12051325

PMid:32392706

15. Samur G, Akkuş OO, Ede G, Ayaz A, Akyol A, Akkuş M, Danışman N. Nutritional status among women with preeclampsia and healthy pregnant women. Prog Nutr. 2016;18(4):360-8.

16. Mousa A, Naqash A, Lim S. Macronutrient and micronutrient intake during pregnancy: An overview of recent evidence. Nutrients. 2019;11(2):443. https://doi.org/10.3390/nu11020443 PMid:30791647

17. Fox R, Kitt J, Leeson P, Aye CY, Lewandowski AJ. Preeclampsia: Risk factors, diagnosis, management, and the cardiovascular impact on the offspring. J Clin Med. 2019;8(10):1625. https:// doi.org/10.3390/jcm8101625

PMid:31590294

18. Berliana SM, Kristinadewi PA, Rachmawati PD, Fauziningtyas R, Efendi F, Bushy A. Determinants of early marriage among female adolescent in Indonesia. Int J Adolesc Med Health. 2021;33(1):32-44. https://doi.org/10.1515/ijamh-2018-0054

19. Ulhaq RA, Anis W, Fatmaningrum W, Akbar MI. Association between pre-pregnancy body mass index and gestational weight gain and the risk of preeclampsia: A systematic review and meta-analysis. Asian Pac J Reprod. 2021;10(1):1-10. https://doi.org/10.4103/2305-0500.306431

20. oast E, Jones E, Lattof SR, Portela A. Effectiveness of interventions to provide culturally appropriate maternity care in increasing uptake of skilled maternity care: A systematic review. Health Policy Plan. 2016;31(10):1479-91. https://doi. org/10.1093/heapol/czw065

PMid:27190222

21. Khowaja AR, Qureshi RN, Sheikh S, Zaidi S, Salam R, Sawchuck D, et al. Community's perceptions of pre-eclampsia and eclampsia in Sindh Pakistan: A qualitative study. Reprod Health. 2016;13 Suppl 1:36. https://doi.org/10.1186/ s12978-016-0136-x

PMid:27357953

22. Diana $R$, Rachmah $Q$. Nutrition intervention of pregnant adolescents: A systematic review. Nutr Food Sci. 2020;51(2):234-43. https://doi.org/10.1108/nfs-03-2020-0096

23. Schoenaker DA, Soedamah-Muthu SS, Mishra GD. The association between dietary factors and gestational hypertension and pre-eclampsia: A systematic review and meta-analysis of observational studies. BMC Med. 2014;12:157. https://doi. org/10.1186/s12916-014-0157-7

PMid:25241701

24. Symington EA, Baumgartner J, Malan L, Zandberg L, Ricci C, Smuts CM. Nutrition during pregnancy and early development (NuPED) in urban South Africa: A study protocol for a prospective cohort. BMC Pregnancy Childbirth. 2018 24;18(1):308. https:// doi.org/10.1186/s12884-018-1943-6 PMid:30041623

25. Dewi NU, Mahmudiono T. Effectiveness of food fortification in improving nutritional status of mothers and children in Indonesia. Int J Environ Res Public Health. 2021;18(4):2133. https://doi. org/10.3390/ijerph18042133

PMid:33671696

26. Morente F, Ferràs X, Žižlavský O. Cultural innovation models: review and proposal for next steps cultural models of innovation. Univ Empres. 2018;20(4):53-81. https://doi.org/10.12804/ revistas.urosario.edu.co/empresa/a.5433

27. Campinha-Bacote J. The process of cultural competence in the delivery of healthcare services: A model of care. J Transcult
Nurs. 2002;13(3):181-4; discussion 200-1. https://doi. org/10.1177/10459602013003003

PMid:12113146

28. Akeju DO, Vidler M, Oladapo OT, Sawchuck D, Qureshi R, von Dadelszen $\mathrm{P}$, et al. "Community perceptions of pre-eclampsia and eclampsia in Ogun state, Nigeria: A qualitative study. Reprod Health. 2016;13 Suppl 1:57. https://doi.org/10.1186/ s12978-016-0134-z

PMid:27357695

29. Sami J, Quack Lötscher KC, Eperon I, Gonik L, de Tejada BM, et al. Giving birth in Switzerland: A qualitative study exploring migrant women's experiences during pregnancy and childbirth in Geneva and Zurich using focus groups. Reprod Health. 2019;16(1):112. https://doi.org/10.1186/s12978-019-0771-0

PMid:31331344

30. Im EO, Lee Y. Transcultural nursing: Current trends in theoretical works. Asian Nurs Res (Korean Soc Nurs Sci). 2018;12(3):157-65. https://doi.org/10.1016/j. anr.2018.08.006

PMid:30179700

31. Roberts JM, August PA, Bakries J, Barton JR, Beirnstain IM, Druzin M, et al. ACOG Guidelines: Hypertension in Pregnancy; 2012.

32. Ghosh S, Ghosh S. Maternal health and nutrition. Nutr Child Care A Pract Guid. 2004;1-9.

33. Koenig MD. Nutrient intake during pregnancy. J Obstet Gynecol Neonatal Nurs. 2017;46(1):120-2. PMid:27875675

34. Joewono HT, Sulistyono A, Haslinda Y, A. Maternal and perinata outcome of women with obesity in pregnancy. Syst Rev Pharm. 2020;11(2):690-4.

35. Gebreweld A, Tsegaye A. Prevalence and factors associated with anemia among pregnant women attending antenatal clinic at St. Paul's Hospital Millennium Medical College, Addis Ababa, Ethiopia. Adv Hematol. 2018;2018:3942301. https://doi. org/10.1155/2018/3942301

PMid:30245724

36. Lowe SA, Bowyer L, Lust K, McMahon LP, Morton M, North RA, et al. The SOMANZ Guideline for the Management of Hypertensive Disorders of Pregnancy, SOMANZ Guidelines; 2014. p. 8.

37. Brion MJ, Ness AR, Rogers I, Emmett P, Cribb V, Smith GD, et al. Maternal macronutrient and energy intakes in pregnancy and offspring intake at $10 \mathrm{y}$ : Exploring parental comparisons and prenatal effects. Am J Clin Nutr. 2010;91(3):748-56. https:// doi.org/10.3945/ajcn.2009.28623

PMid:20053880

38. Oh C, Keats EC, Bhutta ZA. Vitamin and mineral supplementation during pregnancy on maternal, birth, child health and development outcomes in low-and middle-income countries: A systematic review and meta-analysis. Nutrients. 2020;12(2):491. https://doi.org/10.3390/nu12020491 PMid:32075071

39. Fogacci S, Fogacci F, Banach M, Michos ED, Hernandez AV, Lip GY, et al. Vitamin D supplementation and incident preeclampsia: A systematic review and meta-analysis of randomized clinical trials. Clin Nutr. 2020;39(6):1742-52. https:// doi.org/10.1016/j.clnu.2019.08.015

PMid:31526611

40. Meija L, Rezeberga D. Guidelines: Proper Maternal Nutrition during Pregnancy Planning and Pregnancy: A Healthy Start in Life Recommendations for Health Care Specialists-WHO-OMS. Geneva: World Health Organization; 2017. p. 1-31.

41. Lee SE, Lee MH, Peters AB, Gwon SH. Assessment of patient safety and cultural competencies among senior 
baccalaureate nursing students. Int $\mathrm{J}$ Environ Res Public Health. 2020;17(12):4225. https://doi.org/10.3390/ ijerph17124225

PMid:32545746

42. Kaihlanen AM, Hietapakka L, Heponiemi T. Increasing cultural awareness: Qualitative study of nurses' perceptions about cultural competence training. BMC Nurs. 2019;18:38. https:// doi.org/10.1186/s12912-019-0363-x
PMid:31440116

43. Hussen SA, Kuppalli K, Castillo-Mancilla J, Bedimo R, Fadul N, Ofotokun I. Cultural competence and humility in infectious diseases clinical practice and research. J Infect Dis. 2020;222 Suppl 6:S535-42. https://doi.org/10.1093/infdis/jiaa227 PMid:32926742

44. Bengre A. Transcultural nursing: Cultural competence in nurses. Int J Nurs Educ. 2012;4(1):5-7. 